\title{
Discussion on Postgraduate Education and Management in Colleges and Universities
}

\author{
Lu Tian, Yuguang Lv*, Hengxing Ren, Yaxin Zhao, Ziran Zhou, Peng Lin \\ College of Pharmacy \\ Jiamusi University \\ Heilongjiang, Jiamusi 154007
}

\begin{abstract}
This paper expounds the importance of postgraduate education and management methods in Colleges and universities, aiming at improving the teaching effect of postgraduate education in colleges and universities and enhancing students' practical abilities, problem analysis, problem-solving ability and innovation ability. This paper summarizes the reform achievements in the selection of research projects, the improvement of teaching methods, teachers' level and students' level in postgraduate education, and puts forward new ideas on how to further improve students' innovative consciousness and scientific research ability. Through its continuous deepening and improvement, students' ability can be improved in an all-round way.
\end{abstract}

Keywords-Postgraduate teaching method; Teaching and management; Teaching mode; Research

\section{INTRODUCTION}

The 21st century is an important period. Human society is facing enormous challenges and profound changes. What's more, science and technology develop rapidly. In addition, innovation has become a hot topic in the contemporary era. The competition of overall national strength of countries around the world is increasingly reflected in the competition of highquality talents. Postgraduate education is regarded as a kind of higher education, which is deeply concerned by the masses. At present, postgraduate education has a higher level in China and has trained a batch of high-level talents for our society, which has promoted the prosperity and development of economy, education culture, and social progress vigorously. Under the background of informatization in the new era, the rapid development of society is inseparable from the contribution of postgraduate students. At present, China is a developing country. The progress of a country cannot be separated from the efforts of high-quality talents. In order to implement the strategies for the rejuvenation of the Chinese nation through science and education and strengthen our development in human resource, colleges and universities should do their utmost to train more high-level talents for the society. With the continuous expansion of postgraduate enrollment and the trend of diversified education, the work management on postgraduate education will face more unforeseen challenges. Currently, the primary task for the department of educational management is how to better develop in a complex environment and how to improve the quality of postgraduate education management. Positive insights into the loopholes in education management and real-time updating of education management methods have

The leader of academic research and education, 2017 Jiamusi University education research hundred works

Corresponding author. E-mail address: yuguanglv@163.com played an immeasurable role in the sustainable development of postgraduate education.

\section{CURRENT Status OF Postgraduate EducAtion MANAGEMENT IN COLLEGES AND UNIVERSITIES}

\section{A. The meaning of postgraduate education management}

The management of postgraduate education is that administrators organize and utilize various resources to complete the management work of enrollment, training, degree, etc., which is an activity to achieve postgraduate management goals. The administration of postgraduate education can be divided into broad sense and narrow sense. The broad sense of postgraduate education management is the management of postgraduate education by administration department. The narrow sense of postgraduate education management is the internal management of postgraduates.

\section{B. The Establishment of Postgraduate Education System in China}

It is very tortuous to establish postgraduate education system in China. After the founding of New China, in order to achieve the goal of combining graduate education management with China's social and economic development, the Ministry of Higher Education has established a system suitable for its own national conditions which adheres to the socialism as the direction of running a school and integrates theory and practice, to guarantee the quality. According to the development status in our country, innovation is what we are doing and a comprehensive graduate education system has been established. We have realized the combination of the country, the region, the school and local government in the management mechanism of postgraduate education in China's institutions of high learning. Education management department also plays an important role in the management of local postgraduate education. To standardize the management of postgraduate education accurately, schools' leaders have also established management mechanisms related to postgraduate enrollment and education.

\section{The number of postgraduates has increased sharply}

According to the survey statistics, since 1998, postgraduate education has formally entered the stage of development. The number of postgraduate students has continued to rise in recent years. In 2019, the number of the registration for examination has reached 2.85 million, which is the largest number in history. With the increasing number of postgraduate 
students, it becomes more difficult for graduate education management work and the traditional graduate management model can no longer meet the needs, thus it imposes a severe challenge on the society.

\section{CHARACTERISTICS OF THE POSTGRAdUATE STUdENT GROUP}

Postgraduates' ideological characteristics. Students who choose to study for postgraduate generally have mature ideas and a clear positioning for their own life direction. They pay more attention to develop their own abilities, enhance their own values and have high expectations for themselves[1]. Under the influence of the bad atmosphere of modern society, graduate students have made some changes in their value. They concentrate on the gains and losses of personal interests and material levels, which have strong vanities. The organizational concept and collective consciousness are relatively weak, what's worse, value orientation tends to be utilitarian.

Postgraduates' study characteristics. Postgraduate professional knowledge is abundant, whose self-learning ability is strong and the methods of thinking problems are broad. More importantly, they can systematically master what they have learned. However, students are weak in communicating and cooperating with others. On the one hand, in recent years, universities have continued to expand enrollment, and the number of graduate students has increased, which results in the problem that tutors have no enough energy to guide each student in all aspects. On the other hand, the reason why postgraduate students want to graduate smoothly with only strengthening academic study and ignoring the improvement of individual comprehensive quality is that the assessment in the current stage of schools pays more attention to the development of students' academic ability. Postgraduates' status quo is that they are older than undergraduates and they need to take the school, job, family, etc. into consideration. Therefore, they bear life pressures and psychological pressures[2].Furthermore, the rapid development of social economy and the fierce competition in the workplace increases, which has greatly enhanced the burden of graduate students in employment and the economy.

\section{THE DEVELOPMENT TREND OF GRADUATE EDUCATION IN VARIOUS COUNTRIES}

With the rapid development of society, graduate education is generally valued by all countries. Due to different national conditions, graduate educations in various countries present rich personality characteristics in the development process. Whereas, in accordance with the development and reform of postgraduate education in various countries, there are obvious similar features, which has formed a new development trend that are mainly reflected in three aspects: 1 . Paying more attention to improving the quality of education. 2. Strengthening the connection between colleges and society, making graduate education more suitable for the needs of modern social life. 3. Valuing and promoting liberal arts education. These trends indicate that countries all over the world not only attach importance to the internal factors for the development of graduate education but also lay emphasis on the relationship between graduate education and the external environment, which has great enlightening significance for the development of postgraduate education in China.

\section{PRoblems In the Management of Graduate EDUCATION IN CHINA}

\section{A. Problems in Management Content}

1) Moral education management has been neglected. Graduate students are high-level talents in our country. Their moral level is related to China's development prospects. Although the mental state of graduate students is generally excellent, there are still some problems. Academic integrities and moral issues are not uncommon. In addition, driven by the interests of the market economy, individual tutors who excessively pursue material, fame and fortune are affected by the bad atmosphere of society, which brings negative influence to students.

2) Mental health education management is not paid enough attention to. Since the enrollment expansion of graduate students in 2003, the number of graduate students has increased and its structure is complicated. Furthermore, the current cruel forms of employment, as well as the life problems, have greatly increased the psychological pressure and burden on current graduate students.

3) Postgraduate employment guidance is inadequate. Graduate employment is a complex issue. Postgraduate training on employment is not sufficient, which makes them face serious employment problems[3], As a place for cultivating postgraduate, in order to improve their employment confidence and adaptability, colleges and universities should intensify employment management and guidance,

\section{B. The Deficiency of Postgraduate Self-management}

Postgraduate self-management awareness is weak and selfmanagement atmosphere is not strong enough. Selfmanagement is a special way for postgraduate education management to use the inherent constraints. Only in this way can they discover, analyze and solve problems. Postgraduate self-management awareness is relatively unsubstantial. Some postgraduates are not self-disciplined, and therefore, the subjective initiative cannot be fully utilized in the learning process. Additionally, the atmosphere for guiding them in selfmanagement is not stabilized. Therefore, the graduate students will be able to adapt flexibly to the development of society in the future. We should correctly guide graduate students to selfmanagement and change the situation in which selfmanagement awareness is weak.

\section{The Unbalanced Structure of postgraduate education in Colleges and Universities}

The quality of postgraduate education should be coordinated with the economic development of the country. Postgraduate education which has a tight correlation with employment is more inclined to students' applied subject education and vocational education in abroad. Our country attaches more importance to the quality of education and neglects the cultivation of professional talents. While the 
number of postgraduate students is increasing, education leaders should pay more attention to the construction of educational structure. It is important that postgraduate education should focus on the development of students' knowledge education and skills education. Educators should make a point of mutual penetration with other disciplines when students are imparted knowledge. Besides, postgraduates' papers attach importance to its form and lack sufficient innovation ability.

\section{The form of postgraduate enrollment is too single}

Postgraduate admission exam takes in the form of a unified examination system in China[4]. The biggest drawback of the system is that it cannot test students' ability to actually think and study through examinations. The arrange of examinations schedule is also lack of rationality, which has brought conflicts between postgraduate entrance exam and job hunting. The current system is not fair enough in the enrolment process, especially in the re-examination and adjustment.

\section{E. Informationize construction of education management work is not perfect}

With the continuous development of social economy, the informationize management mode has become very popular in education. Nonetheless, the number of postgraduates is growing fast and informationize construction in education management work is not perfect, which greatly reduces the efficiency and quality of postgraduate management. Now, the graduate education management platform has limited functions and management methods are indistinct. It's difficult to know students' situation in time. And it is impossible for schools to supervise the whole process of postgraduate education management. Hence, the postgraduate informationize education management platform should be further improved.

\section{EFFECTIVE SUGGESTIONS ON STRENGTHENING THE} QUALITY OF POSTGRADUATE EDUCATION MANAGEMENT IN CHINA

\section{A. Improving the content of postgraduate education management}

1) First, it should improve the management of moral education for postgraduate students. It should determine a person's comprehensive ability and show a person's inner qualities. Therefore, the ideological education work of postgraduate students plays an indispensible role in the management of postgraduate education in universities. Postgraduates are older and mature and have the abilities of learning. On the whole, it is very different from undergraduates. Undergraduates don't need to think too much and they don't have such a big pressure and psychological burden; postgraduates will face more unknown challenges. The current society emphasizes one's education background in the work, so more and more people choose to continue to study in their majors so as to get a promotion and raise their salary. They do not simply acquire knowledge, enhance individual capacities, and become utilitarian. Therefore, universities need to strengthen the development of ideological and political education, guide postgraduate to correctly understand the relationship between personal interests and collective interests and do not pay much attention to personal gains and losses, establish a correct values and views on life, strive to create a good campus atmosphere and improve the comprehensive quality of postgraduates. At the same time, colleges and universities should also organize more collective activities, enhance the sense of unity and collective honor of postgraduates and improve the effectiveness of postgraduate education management.

2) Second, the importance of management of postgraduate mental health education. Graduate students bear a lot of life stress and psychological burden. Research that postgraduate psychological problems should be strengthened in postgraduate education management personnel in universities and it should pay close attention to the psychological problems of graduate students[5]. Graduate students are so unsociable that they are easy to make some extreme behavior. The school can establish a campus counseling room to freely solve the psychological problems and provide protection for the mental health of graduate students. It can also enrich the cultural life on campus, enable graduate students to participate in activities and enjoy happiness in their study and life.

3) Third, it should strengthen postgraduate employment guidance education. It should do a good job in postgraduate employment guidance and take part in more career education activities. To cultivate students' adaptability in the interview process and improve their employability skills, it should know and evaluate them correctly, find out own deficiencies and correct them. Only by guiding students to establish a correct employment view and career choice view can students make every effort to find ideal jobs.

4) Fourth, it should increase investment in postgraduate education resources. Because of the implementation of the enrollment expansion plan, the number of graduate students has increased and the scale has become larger. However, the rate of investment in postgraduate education resources is not proportional to the growth rate of postgraduate students. There have been a series of problems in classroom and laboratory, and dormitory are very simple; the number of instruments and equipment is limited and cannot meet the needs of the experiment. Therefore, schools should pay attention to the construction of infrastructure and the introduction of instruments and equipment, increase investment in postgraduate education resources and improve conditions for postgraduate study, life and experimentation, which can make postgraduate have a good learning and living environment and improve the efficiency and quality of work. In addition, schools should also start some scientific and technological activities, innovation and entrepreneurship competitions, etc., support in funding and technology, encourage graduate students to apply for subject, conduct academic research, and carry out innovative projects. 


\section{B. Correctly guide graduate students to self-management}

In the new era, remarkable results have been made in the management of postgraduate education in universities. It is not enough to rely on the management of the school. It requires the cooperation between postgraduates and schools. Postgraduate students should have initiative spirits, promote comprehensive capacities and achieve self-education and self-restraint. Students who are noble should spare no efforts to strive to improve the academic level while keeping up with the level of thought. To be comprehensive development graduate students, students can respect for the development of individuality, improve their professional knowledge and skills and cultivate innovative thinking while developing generality.

\section{Adjusting the educational structure of postgraduates in colleges and universities}

On the basis of ensuring the coordination of graduate education quality and economic development, leaders pay attention to the education of professional disciplines, insist on giving priority to students' knowledge education and skill education. It is necessary to infiltrate relevant disciplines while imparting knowledge to students. In addition, in scientific research experiments, we should add our own views and opinions. When writing papers, we should not pursue form, but be innovative

\section{Reforming the enrollment and selection system}

It should guarantee the quality of postgraduate enrollment work. The postgraduate student enrollment selection system should be suitable for the current situation of education development. In the process of enrollment, we should pay attention to examine the innovative ability of candidates. First of all, the admission examination should focus on professional knowledge and adjust the proportion of basic knowledge and professional knowledge. In addition, in the process of postgraduate re-examination, tutors should emphasize students' innovative ability and logical thinking ability, explore the potential of students and strive to cultivate better talents for the country

\section{E. Establishing a comprehensive information platform for postgraduate education management}

Nowadays, the network has been closely related to people's life, which brings great convenience to people. People can not only enrich their knowledge reserve through the network, but also improve the efficiency and quality of education management. Therefore, in the management of graduate education, we should take advantage of the merits of the Internet to construct a scientific and complete education management system and establish a comprehensive network supervision and management platform[6]. On a comprehensive information management platform, graduate students' personal information, academic record, and course can be managed in different modules and each module restricts and supports each other. The result is an efficient graduate education management platform, which can not only manage graduate students in an all aspects, but also improve the scientific and efficient management of education.

\section{CONCLUSION}

All in all, the management of postgraduate education in colleges and universities is important. And improving the work will be a difficult and lengthy process. In this process, both the cooperation between postgraduate education administrators and postgraduate students and the support and encouragement of schools and countries are needed. It is also necessary to formulate corresponding solutions to existing problems in the management of postgraduate education and further enhance the comprehensive level of graduate students. To explore new management models, the administrators of postgraduate education in colleges and universities should also deeply analyze the shortcomings in the management work, enhance their own quality and ability, summarize experience and lessons and adapt to the development of the times. Education leaders should aim at cultivating high-quality talents with good moral sentiments and high professionalism, contribute themselves to the progress and development of society and promote the vigorous development of graduate education in China.

\section{REFERENCES}

[1] Hui Zhang, Lu Yang, Qian Zhang. Exploration and Research on the Management Model of Graduate Education[J]. Contemporary Educational Practice and Teaching Research, pp. 112-113, 2017. (In Chinese)

[2] Xiangjun $\mathrm{Xu}$. Problems and Countermeasures of postgraduate education management in Colleges and Universities[J]. SME management and technology, vol. 20, pp. 20-21, September 2017. (In Chinese)

[3] Fangguan Wang. Discussions on the deviation and countermeasure of postgraduate education management in China's universities[J]. Western quality education, pp. 25, 2015. (In Chinese)

[4] Yuhong Zhong, Minli Qiu, Di Tian. Current situation and improvement measures of graduate education management in colleges and universities[J]. Higher education journal, pp. 128-129, 2017. (In Chinese)

[5] Bo Hong. Research on the current situation and countermeasure of graduate management team in colleges and universities[J]. Educational circles: research on higher education, pp. 8, 2015. (In Chinese)

[6] Caihong Liu. Problems and countermeasures in the management of postgraduate education[J]. Journal of Hubei correspondence university, vol. 28, pp. 1-6, September 2015. (In Chinese) 